\title{
Ethnobotany Home garden in Puspa Jagad Tourism Ecology Area Semen Village, Gandusari District, Blitar Regency
}

\author{
Purnomo ${ }^{1 *}$, Jati Batoro², Abdul Hakim \\ ${ }^{1}$ Master Program of Environmental Resources Management and Development, University of Brawijaya, Malang, \\ Indonesia \\ 2Department of Biology, Faculty of Mathematics and Natural Sciences, University of Brawijaya, Malang, Indonesia \\ ${ }^{3}$ Faculty of Administrative Sciences, University of Brawijaya, Malang, Indonesia
}

\begin{abstract}
Home garden is one form of sustainable agricultural land management. Home garden is important as a local identity in a society especially in rural areas. The purpose of this research is to describe the uniqueness and distinctiveness of the home garden which includes the elements of the home garden, plants species diversity and ethnobotany value of plants in Puspa jagad Ecological tourism area. Data collection is done by observation to find out the elements of the home garden and plants species diversity component. Interviews were also conducted to obtain data on the management of the home garden and ethnobotany values of plants which included ICS (indexes of cultural significance) and UVS (Use Value species). The home garden elements in Puspo Jagad ecological tourism area consist of ngarepan (home garden located in front of the house), kiwo-tengen (home garden located right and left of the house), mburitan (home garden located behind the house), joglangan (traditional bio pore well as a place for water infiltration as well as an organic waste bin), peceren (holes as well as waste disposal sites from activities at home), cattle sheds, wells, bathroom and toilets. Plant diversity on heme garden consists of 151 species of 132 genus and 61 plant families. These plants are grown in general to beautify the environment around of the house. The stratified plant canopy vertebration on home garden in Puspo Jagad Toursm Ecology Area are dominated by stratum E,D and C Based on the results of the calculation of ICS or Cultural Interest Index shows that the needs of the community depends largely on the local natural resources around. Based on ICS and UVS values, coconut (Cocos nucifera) and banana (Musa acuminata) plants are the plants that have the highest value, this is because these plants have many parts that can be utilized and are widely used for daily needs.
\end{abstract}

Keywords: ICS, identity, plant, UVS.

\section{INTRODUCTION}

The home garden is one of the most common, important and widely cultivated land management practices in Indonesia, besides rice fields and moorings [1]. The size of the home garden in Indonesia in 2011 is about 10,300 thousand hectares or $14 \%$ of the total agricultural land area. The yard of the house is also considered a traditional home garden which in the management of the land combines various useful plant species, livestock and fishery in it [2]. The main characteristic of the home garden is the presence of residential elements, the diversity of plants whose composition depends on the needs of the owner $[3,4]$.

The characteristics of land can be said as a home garden is located around the residence or around the house, has a variety of forms according to the geographical and cultural conditions of society, part of the agricultural land for the owner and has clear boundaries. The home garden is considered sustainable environmental management. This is because in the management of this home garden there are elements that contain the values of conservation, economic and social-culture of the local community.

Conserving home gardens is one of the in-situ conservation strategies, especially the conservation of plants, although there are also a variety of wild animals and animals that are involved in building a living network within them [5]. In the home garden of Tenggerese, Anaphalis sp. was found; a rare plant typical of the mountains are. The existence of this plant, as a cultivation plant is one form of conservation of insitu [5].

Culture home garden is important as a local identity in a society, especially in rural areas. As a result of culture, the home garden in each region in Indonesia certainly has various types or specific models that are unique and distinctive according to the geographic condition and the culture of the

\footnotetext{
${ }^{*}$ Correspondence address:

Purnomo

Email : purnomo2006@gmail.com

Address : Postgraduate School, University of Brawijaya, Mayjen Haryono No. 169, Malang 65145
} 
society that exists. The home garden has special characteristics with the community groups that own it or in other words the existence of a home garden has a relationship with a community group. In addition, the home garden in it also contains elements of conservation, especially plants. Types of plants that grow in the home garden are also influenced by the geographical conditions in which the home garden of the house is located $[3,6]$.

The uniqueness and distinctiveness in the form of horizontal and vertical vegetation structure and home garden management can be used as a tourism attraction, especially along the route of the tourist area or in the villages designated as the tourist village area. Rural tourism is a tourism product that was built to introduce rural tourism attractions. Tourist village is a form of sustainable based tourism practice. Through the development of tourist village is expected to improve the standard of living of the community, conservation of natural resources and culture in the community [6].

The home garden in Eco-tourism Village of Puspa Jagad can be identified from the structure of the vegetation composition, horizontally and vertically as well as the composition of its farm animals and fisheries. It is also necessary to study its ethnobotany, thus we can know the mutual relationship between human with the plants in the yard of the house. Typical home garden model is a uniqueness of its own. This uniqueness can be part of the attractions in tourist areas such as Puspa Jagad Ecotourism for the tourist attractions. This study aimed to describe the home garden uniqueness in the ecological tourism area of Puspa Jagad, Blitar.

\section{RESEARCH METHODS \\ Study Area}

This research was conducted in Semen Village, one of the villages in Gandusari District, Blitar Regency. The village has an area of approximately $1,079.12$ ha. The topography of the area is undulating with an average height of $497 \mathrm{~m}$ above sea level.

\section{Data collection}

The data was collected by observation on the types of home garden compounds. The plants that are found are directly induced by local names, scientific names, families and their benefits. Observations also made on home garden typology include information on the elements of the home garden, the area of the home garden and the existence of domestic plants and livestock. Elements of the home garden, in general, include frontal expertise, backyard, side yards, kitchen, the existence of wells and bins. Interviews were conducted to obtain data on the management of home garden and cultural aspects in it in depth. In addition, interviews are also conducted to find out the various benefits of these crops by the community.

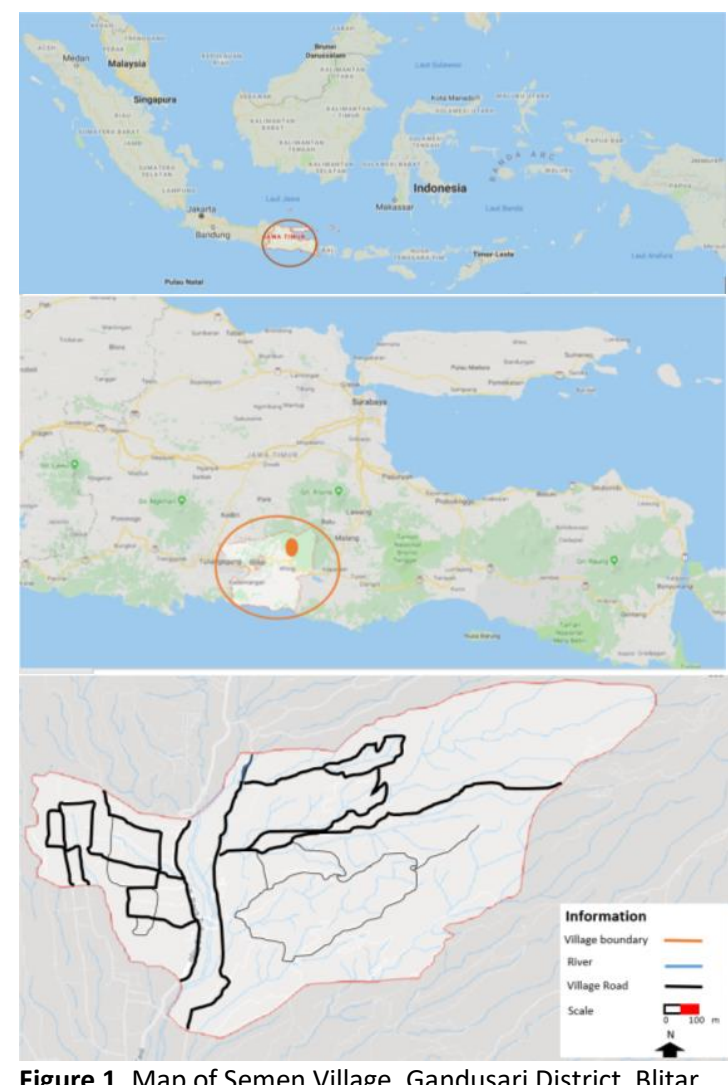

\section{Data analysis}

Based on the benefits of plants grown in home plants, it can know the cultural value (ICS) and use value (UVS) for each plant. ICS calculations aim to determine the most important or most useful types of plants for human life [7]. ICS is done using the following formula:

$$
I C S=\sum_{i=1}^{n}(q \times i \times e) n_{i}
$$

\section{Description:}

$\mathrm{n}=$ usefulness value of a last plant species

$q=$ value of quality on the use of a plant species

$5=$ for main foodstuff

$4=$ food additives and main ingredients

$3=$ other food + secondary material and ingredients of traditional medicine

$2=$ material for ritual, myth and recreation and value 1 $=$ only known usefulness only.

$i=$ intensity value on the usefulness of plant species 


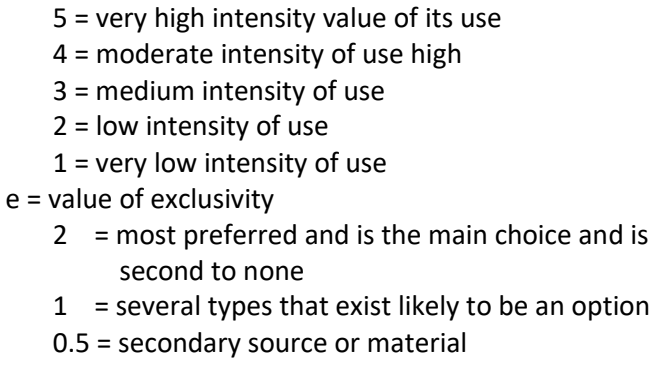

UVs are the use of a plant that is utilized by the community [7].

$$
U V S=\frac{\sum U V i s}{n_{i}}
$$

Description:

UVs = Value Use Species

UVis $=$ the number of mentioned uses of a species

$\mathrm{ni}=$ Total number of respondents interviewed

\section{RESULT AND DISCUSSION}

Plants in the home garden of Puspa Jagad

The home garden on a local language in Puspo Jagad Tourism Ecology Area is called a pecuren. The land is said to be a pecuren characterized by clear boundaries in the form of fences from certain plants (Cordyline fruticosa (L.) A. Chev.) or bamboo. Besides that the ground floor of the home garden is relatively clean from litter and weed plants. This is what distinguishes other land around the home garden, for example moor.

Other than a pecuren, also called a tanah, tanah is an abbreviation of the local language which means tatanen sing pernah or meaning manage the land well. This shows that the existence of the home garden in Puspo Jagad Tourism Ecology Area very closely with the management carried out by the owner.

Based on the research, it is known that in the home garden, there are 151 species of 132 genus and 61 plant families. These plants are grown in general to beautify the environment around of the house as well as to meet daily needs. The home garden are part of a small-scale plant biodiversity community. Plants that exist in the home garden system represent the choices and interests of the community [8]

In general, the stratification of plant canopy in the home garden of the Puspa Jagad Ecological Tourism Area is dominated by strata E, D and C. Whereas plants that have $B$ and $A$ stratification are rarely found in the yard of the house, except in a relatively large home garden. Usually plants that have $A$ and $B$ stratification are found some distance from the main building. This is due to the canopy trimming of plants that should have tree leaves. The existence of plants with stratification
$A$ and $B$ that are adjacent to the building is feared to be able to damage the building. This is different from most home gardens in the tropics including Indonesia which has complete stratification [9].

Stratification of plants on home garden in Puspa Jagad Ecological Tourism Area which are dominated by the status of $E, D$ and $C$, this is possible this region is an area with contour of hilly land between the Kelud and Kawi mountains [9]. Other areas in areas with contour of hilly land such as Ngadas village, Poncokusumo District, Malang Regency and Ranu Pani Village, Senduro district Lumajang Regency, which is also located in the mountainous areas of the home garden plants, which are dominated by plants with $\mathrm{E}$ and D strata with horticultural plants [11].

Stratification is a vertical distribution of plants. Where each plant species in the community has different height measurements. These plant stratifications are grouped into five categories $E$, D, C, B and A. Strata E are plants with a high category of less than $1 \mathrm{~m}$. strata $D$ is plants with a high category between 1- $4 \mathrm{~m}$. strata $C$ is plants with a high category between $4-20 \mathrm{~m}$. Strata B is plants with a high category between $20-30 \mathrm{~m}$. Strata A are plants with a high category of more than $30 \mathrm{~m}$ [12].

Plants grown in the home garden have many important functions, but in general, the land of the home garden is used for ornamental plants or useful plants which as an ornamental plant. So generally the plants in home garden are classified into pure ornamental plants and plants that are useful but also functioned as an ornamental plant. Non-ornamental plants are used as food crops, wood, industry, medicine, and others [13]. Based on the results of the Interview, it is known that the home garden has an important value for the people in Puspa Jagad Ecology Tourism Area.

Horizontal home garden is divided into three regions based on its layout of the house, namely front home garden or in a local language called ngarepan, side home garden or in a local language called kiwo-tengen, and back home garden or in a local language called mburitan. Front porch is dominated by ornamental plants because it is a reflection of homeowners, if the home garden is narrow and to add the beauty of the home, they add ornamental plants grown in pots. The front home garden is also used to dry the agricultural crops such as coffee or dried cassava. Meanwhile, the home garden which is located at the left of the house is usually used to place the clothes drying or place to dry the wood. While the backyard functioned as a place of livestock. In addition, the 
rear home garden also functioned as a place of firewood and bathroom.

Plants behind the house are usually large plants or plants that require a large area. Elements on the home garden in Puspa Jagad area is fence, joglangan, peceren, livestock pens, wooden place, clothesline, bathroom and well (Fig. 2 and 3). These elements have a bond with the homeowners. Home garden is largely limited by the various plants which are arranged in such a way so that there is a boundary or fence between one home gardens with other land units. Plants used for the compilers of this fence are generally a plant that is easily planted, e.g. from cuttings.

Joglangan is a hole made with a size of about $2 \times 2 \mathrm{~m}$ with a depth of $1.5 \mathrm{~m}$. This joglangan is used as a garbage container for the leaves of the fallen leaves from plants of the home garden. Peceran is a place to accommodate household wastewater from bathroom and kitchen. Peceran is usually planted with Pekiwon plants. Pekiwon Plants that usually exist in home garden are pandanus (Pandanus amaryllifolius), Dringo (Acorus calamus), Suji (Dracaena angustifolia) and etc. These plants are phytoremediation plants that can absorb pollutants $[14,15]$.

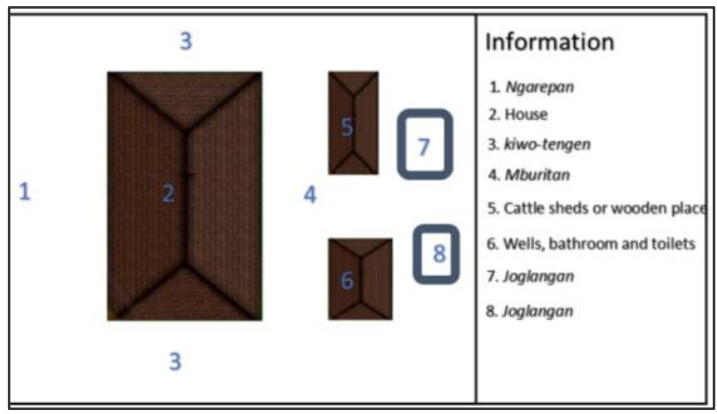

Figure 2. The elements of the house In Puspa Jagad Tourism Ecology Area

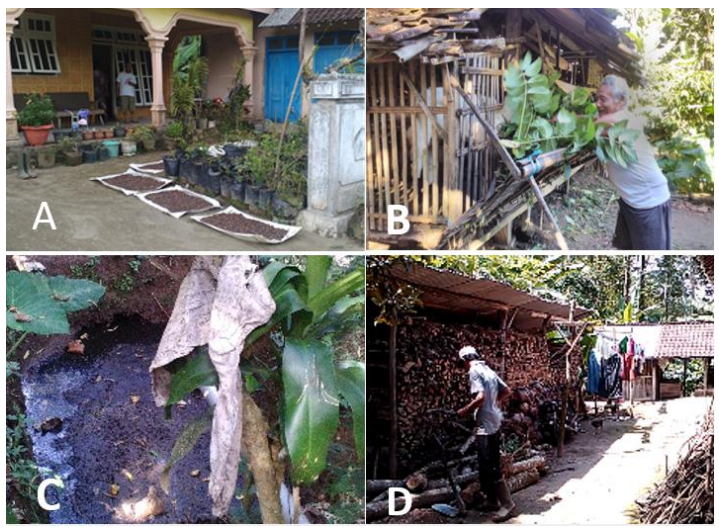

Figure 3. Home Garden Elements.

Description: A. The front of the house used to dry the harvest, $B$. cattle pen, $C$. Peceran and D. firewood warehouse

\section{ICS and UVS Value}

The results of the calculation of ICS or Cultural Interest Index show the needs of the community. Based on the value of ICS, Cocos nucifera or coconut is a plant that has the highest value in Puspa Jagad tourism area (Table 1). This is because the coconut plant is a multifunctional plant, e.g. for food, woody materials called Glugu, wood fuel, medicines and others. Another high ICS values are bananas, sugarcane and empon-empon or herbs plants (such as turmeric, galanga and etc).

Table 1. ICS Value

\begin{tabular}{cllr}
\hline No & Species & Local Name & ICS \\
\hline 1 & Cocos nucifera & Kelapa & 119 \\
2 & Musa paradisiaca & Pisang & 102 \\
3 & Saccharum officinarum & Tebu ireng & 44 \\
4 & Alpinia galangal & Laos & 42 \\
5 & Curcuma longa & Kunir & 42 \\
6 & Boesenbergia rotunda & Kunci & 42 \\
7 & Ipomoea batatas & Ubi jalar & 41 \\
8 & Manihot esculenta & Singkong & 41 \\
9 & Pennisetum purpureum & Rumput gajah & 40 \\
& Artocarpus & & \\
10 & heterophyllus & Nangka & 36 \\
11 & Capsicum annuum & Lombok & 30 \\
12 & Pandanus amaryllifolius & Pandan & 29 \\
13 & Coffea canephora & Kopi & 28 \\
14 & Syzygium polyanthum & Salam & 27 \\
15 & Durio zibethinus & Durian & 26 \\
16 & Zingiber officinale & Jahe merah & 26 \\
17 & Carica papaya & Pepaya & 24 \\
18 & Calliandra calothyrsus & Kaliandra & 24 \\
19 & Vigna unguiculata & Kacang panjang & 24 \\
20 & Manglietia glauca & Kayu kembang & 24 \\
\hline
\end{tabular}

Coconut plants in the tropics generally in Indonesia are important plants and are known as multifunctional plants. Plant parts such as leaves, flowers, fruit and stems can be used for daily use [16], included in various customary rituals in Java. This is because in this tree has the noble philosophies. Coconut fruit called Cengkir Gading is an important means of custom rituals such as for Mitoni (baby shower), wedding ceremony and etc. This is because Javanese society seen it as a plant that represents the symbol of the hope, so that humans have Cengkir Gading or Kenceng Ing thought, which can be interpreted as a strong thought to achieve goals. It is describe the strong determination and mind in achieving the purpose of life. In the ceremony of Siraman as part of pre wedding ceremony in Javanese culture, two green coconuts are tied in the husk, sprinkled with water and flowers. This coconut is a symbol of hope for the eternal marriage until the end of life. Green coconut is also considered a plant that symbolizes the glory and the bearer of sustenance. 
Young yellow coconut leaves called Janur Kuning is often used as decoration or symbols in various traditional ceremonies. Linguistically, the word Janur Kuning comes from the word Jan which is defined as Jannah. Jannah is an Arabic word meaning heaven, Nur means light, and Ning means Wening or holy. So, yellow coconut here is meant to remind the two brides to have the holy feelings towards each other. It also mean that humans in reaching a holy goal must be intended because of God.

In the Javanese wedding ceremony, Janur Kuning (yellow leaf of coconut) is also used as a symbol of hope for a beautiful household. Janur Kuning in the wedding ceremony is usually used as decoration and Kembar Mayang. In the use of this leaf, it should not be cut, but teared. This is as a symbolization and Piwulang to the bride so that later in marriage, if they face various problems in their life, althought their heart feels like teared apat, they must remain steadfast and keep the household not to break or divorce.

Other tourism area such as Tengger, ecologically, we can not found coconut trees because it has topography above $1,800 \mathrm{~m}$ asl. However, Tenggerese still see coconut as an important part in everyday life, including in traditional ceremonies. This can be seen from Ongkek or offerings made by shamans in Kasada, Unan-Unan or Karo ceremony which always include the fruit of coconut (Cengkir Gading) and Janur. Tenggerese perception on the whole coconut tree is a mystical portrayal of human life [17]. The ritual component of the tengger community originating from coconut plants are $30 \%$ [18].

In Tambaksari Village of, Purwodadi District, Pasuruan Regency, East Java Province coconut plants also have the highest ICS value. This is because coconut plants have many benefits for the community [19].

In addition to the ICS, we also used UVS, an index that describes the level of value for plant species present in home garden. Based on the UVS index (Table 2), the highest value is a Musa paradisiaca or banana plant with a value of 4 .

The parts of banana that used are stems, flowers, fruits, and leaves. Coconut and Artocarpus heterophyllus or jackfruit plants for the Puspa Jagad community also have high UVS values. This is because this plant has various benefits ranging from leaves, stems, fruits, and seeds. Utilization of these plants ranging from food ingredients, fruits, vegetables, handicrafts, ritual utilization, food wrapping, fodder etc.
In Tambaksari Village of, Purwodadi District, Pasuruan Regency, East Java Province banana plants also have the highest ICS value. Banana plants have a fairly fast growth period and continuously, which results is quite high. Banana fruit can be used in both raw and mature [14].

Table 2. UVS Value

\begin{tabular}{lllr}
\hline No & Species & Local Name & UVS \\
\hline 1 & Musa paradisiaca & Pisang & 4 \\
2 & Cocos nucifera & Kelapa & 3.87 \\
3 & Artocarpus heterophyllus & Nangka & 3 \\
4 & Manihot esculenta & Singkong & 2.43 \\
5 & Carica papaya & Pepaya & 2 \\
6 & Ipomoea batatas & Ubi jalar & 2 \\
7 & Manglietia glauca & Kayu kembang & 2 \\
8 & Lansium domesticum & Duku & 2 \\
9 & Syzygium polyanthum & Salam & 2 \\
10 & Syzygium aromaticum & Cengkeh & 2 \\
11 & Syzygium aqueum & Jambu air & 2 \\
12 & Citrus hystrix & Jeruk nipis & 2 \\
13 & Saccharum offucinarum & Tebu ireng & 2 \\
14 & Xanthosoma sagittifolium & Gote & 1.96 \\
15 & Colocasia esculenta & Bentul putih & 1.96 \\
16 & Durio zibethinus & Durian & 1.61 \\
17 & Coffea canephora & Kopi & 1.48 \\
18 & Cananga odorata & Kenanga & 1.35 \\
19 & Mangifera indica & Mangga & 1.04 \\
20 & Apium graveolens L. & Seledri & 1.04 \\
21 & Amorphophallus paeoniifolius & Suweg & 1.04 \\
\hline
\end{tabular}

\section{CONCLUSION}

The diversity of plants found in the yard of the house (Home garden) in Puspa Jagad Tourism Village Ecology is 151 species of 132 genera and 61 plant families. These plants are grown generally to beautify the atmosphere of the house, due to its shape of flowers, leaves and morphology of plants that are considered attractive. Plants in this home garden are also well utilized to meet the daily needs of the owner. Home garden as part of the growing place of domesticated plants is also the location of livestock.

The stratified plant canopy vertebration in home garden in Puspa Jagad is dominated by strata $E, D$, and $C$. While plants with stratification $B$ and $A$ are rarely found, except house with relatively large home garden and usually found in some distance from the main building.

Based on the results of the calculation of ICS or Cultural Interest Index shows that the needs of the community depends largely on the local natural resources around. Based on the value of ICS and UVS, coconut and banana is a plant that has the highest value, respectively.

\section{REFERENCES}

[1] Darajati, W., P. Sudhiani, H. Ersa, D. R. Antung, S. N. Vidya, N. Bambang, S. R. Joeni, U. Rosichon, M. Ibnu, K. Rachman, A. P. Teguh, R. Alimatul, J. Jeremia and H. Fahmi. 
2016. Indonesian Biodiversity Strategy and Action Plan (IBSAP) 2015-2020. Indonesian Ministry of National Development Planning (BAPPENAS). Jakarta.

[2] Sánchez, A. O., M. O. Columba, R. M. Angélica, L. C. Mario and C. E. Patricia. 2015. Multipurpose functions of home gardens for family subsistence. Botanical Sciences 93(4), 791-806.

[3] Baskara, M. and W. Eko. 2013. Sistem pekarangan permukiman masyarakat di kawasan Karst Jawa Timur Bagian Selatan. Proceeding of Scientific Finding. Association of Indonesian Built Environmental Researcher (IPLBI).

[4] Ashari, S. and B. P. Tri. 2012. Potensi dan prospek pemanfaatan lahan pekarangan untuk mendukung ketahanan pangan. Forum Penelitian Agro Ekonomi 30(1), 1330.

[5] Amberber, M., A. Mekuria and A. Zemede. 2014. The role of homegardens for in Situ conservation of plant biodiversity in Holeta Town, Oromia National Regional State, Ethiopia. International Journal of Biodiversity and Conservation 6(1), 8-16.

[6] Hakim, L. and N. Nakaghosi. 2007. Plant species composition in home gardens in the Tengger Highland (East Java, Indonesia) and its importance for regional ecotourism planning. Hikobia 15(1), 23-36.

[7] Cunningham, A. B. 2001. Applied ethnobotany: people, wild plant use and conservation. Taylor and Francis. New York.

[8] Idohou, R., B. Fandohan, V. K. Salako, B. Kassa, R. C. Gbèdomon, H. Yédomonhan, R. L. G. Kakaï and A. E. Assogbadjo. 2014. Biodiversity conservation in home gardens: Traditional knowledge, use patterns and implications for management. International Journal of Biodiversity Science, Ecosystem Services and Management 10(2). 89-100.

[9] Soemarwoto, O. and G. R. Conway. 1991. The Javanese homegarden. Journal of Farming Systems Research-Extension 2(3). 95-117.

[10] Statistics Center of Blitar Regency. 2018. The Gandusari District in numbers. Blitar Regency.

[11] Subadyo, A. T. 2016. Tengger tribal architecture in the area Bromo Tengger Semeru National Park. Proceeding of Scientific Finding. Association of Indonesian Built Environmental Researcher (IPLBI).
[12] Soerianegara I. and A. Indrawan. 2005. Forest ecosystem in Indonesia. Forest Ecology Laboratory, Bogor Agricultural University. Bogor.

[13] Prihatini, J., J. Iskandar, Ruhyat Partasasmita and D. Nurjaman. 2018. The impacts of traditional homegarden conversion into the commercial one: A case study in Sukapura Village of the Upstream Citarum Watershed, West Java, Indonesia. Biodiversitas 19(5), 1926-1940.

[14] Han, P., P. Kuma and B. L. Ong. 2014. Remediation of nutrient-rich waters using the terrestrial plant, Pandanus amaryllifolius Roxb. Journal of Environmental Sciences (China) 26(2), 401-414.

[15] Bhagwat, R. V., D. Boralkar and R. D. Chavhan. 2018. Remediation capabilities of pilot-scale wetlands planted with Typha aungstifolia and Acorus calamus to treat landfill leachate. Journal of Ecology and Environment 42(23). DOI: 10.1186/s41610-018-0085-0.

[16] Erawan, T. S., S. N. Aya and J. Iskandar. 2018. Ethnobotanical study on coconut plant in Karangwangi Village, Cianjur, West Java. Proceeding of National Seminar of Indonesian Biodiversity Community 4, 163168.

[17] Purnomo. 2015. Traditional practices of environmental conservation in Java. Brawijaya University Press. Malang.

[18] Pramita, N. H., S. Indriyani and L. Hakim. 2013. Etnobotani Upacara Kasada Masyarakat Tengger, di Desa Ngadas, Kecamatan Malang, Poncokusumo, Kabupaten Malang. Journal of Indonesian Tourism and Development Studies 1(2), 5261.

[19] Oktavianti, E. and L. Hakim. 2013. Etnobotani Pekarangan Rumah Inap (Homestay) di Desa Wisata Tambaksari, Purwodadi, Pasuruan, Jawa TimurJournal of Indonesian Tourism and Development Studies 1(1), 39-45. 